\title{
Development of an instrument to evaluate the knowledge that the patient with hepatic cirrhosis has about his disease and treatment
}

\author{
Desenvolvimento de um instrumento para a avaliação do conhecimento que o \\ paciente com cirrose hepática tem sobre sua doença e tratamento
}

\begin{abstract}
Kayo Augusto de Almeida Medeiros ${ }^{1}$, Bárbara Justo Carvalho ${ }^{1}$, Fernanda Nii ${ }^{1}$, Yuri Justi Jardim $^{1}$, Luiz Augusto Carneiro D’Albuquerque ${ }^{2}$, Alberto Meyer ${ }^{3}$, Wellington Andraus ${ }^{4}$
\end{abstract}

Medeiros KAA, Carvalho BJ, Nii F, Jardim YJ, D’Albuquerque LAC, Meyer A, Andraus W. Development of an instrument to evaluate the knowledge that the patient with hepatic cirrhosis has about his disease and treatment / Desenvolvimento de um instrumento para a avaliação do conhecimento que o paciente com cirrose hepática tem sobre sua doença e tratamento. Rev Med (São Paulo). 2018 Nov-Dec;97(6):523-32.

ABSTRACT: Introduction: hepatic cirrhosis (HC) is a disease with high morbidity and mortality in Brazil. Its treatment is complex and requires from lifestyle changes to large surgeries such as liver transplantation. To reach the best treatment results, it is necessary to guarantee a good patient's adherence to the treatment. Studies indicate that the patient's self-knowledge about his or her clinical condition is a determining factor in its adherence. Objectives: to assist in the design of an instrument that evaluates knowledge about the disease and treatment of HC. Methodology: The development process of the instrument will be divided into 3 stages: construction of the instrument (1st stage), evaluation of content validity and clarity of the instrument (2nd stage) and assessment of the reliability of the instrument ( 3 rd stage). Results: an instrument to evaluate the cirrhotic patient knowledge about the disease was made, analyzed by specialists and approved in the criteria proposed. Conclusions: 1) The development of the instrument followed the steps described in literature. 2) The suggestion of the evaluators allowed to restructure the questions making them clearer and more relevant to the proposal of the instrument. 3) it was possible to achieve satisfactorily the proposal of the construction of the instrument.-

Keywords: Liver cirrhosis; Self concept; Surveys and questionnaires; Health education.
RESUMO: Introdução: cirrose hepática $(\mathrm{CH})$ é uma doença com alta morbidade e mortalidade no Brasil. Seu tratamento é complexo e requer desde mudanças no estilo de vida até se submeter a grandes cirurgias, como o transplante hepático. Para alcançar os melhores resultados é necessário que o paciente tenha uma boa aderência ao tratamento. Estudos indicam que o conhecimento do paciente sobre sua condição clínica é um fator determinante na aderência. Objetivos: criar um instrumento que meça o conhecimento que um paciente com CH tem sobre sua doença e seu tratamento. Methodologia: o processo de desenvolvimento do instrument foi dividido em 3 estágios: construção do instrument ( $1^{\circ}$ estágio), avaliação do conteúdo e claridade do instrument ( $2^{\circ}$ estágio) e avaliação da confiabilidade do instrument ( $3^{\circ}$ estágio). Results: um instrument para avaliar o conhecimento do paciente cirrótico sobre sua doença foi feito, analisado por especialistas e aprovado pelos critérios propostos. Conclusions: 1) O desenvolvimento do instrumento seguiu os passos descritos na literatura. 2) As sugestões dos avaliadores foram seguidas na reestruturação das questões, tornando-as mais claras e relevantes para a proposta do instrumento. 3) Foi possível alcançar de forma satisfatória a proposta de construção do instrumento.-

Descritores: Cirrose hepática; Autoimagem; Inquéritos e questionários; Educação em saúde.

Trabalho foi realizado: Hospital das Clínicas da Faculdade de Medicina da Universidade de São Paulo (HCFMUSP). Apresentado no XXXVII Congresso Médico Universitário, na categoria Clinical Area do Oswaldo Cruz Awards, em 2018.

1. Acadêmico da Faculdade de Medicina da Universidade de São Paulo - FMUSP. ORCID: Medeiro KAA - https://orcid.org/0000-0001-8994-1883; Carvalho BJ - https://orcid.org/0000-0002-7599-6610; Nii F - https://orcid.org/0000-0002-5254-4785; Jardim YJ - https://orcid.org/0000-0001-92935310. Emails: kayo.medeiros@fm.usp.br, barbara.justo@fm.usp.br, fernanda.nii@fm.usp.br, yuri.justi@fm.usp.br.

2. Diretor do Serviço de Transplante de Fígado e Cirurgia do Hospital das Clínicas (HCFMUSP), professor e chefe do Departamento de Gastroenterologia da FMUSP. ORCID: https://orcid.org/0000-0001-7607-7168. E-mail: profluizcarneiro@gmail.com.

3. Cirurgião do Serviço de Transplante de Fígado do Departamento de Gastroenterologia do Hospital das Clínicas da Faculdade de Medicina da Universidade de São Paulo - HCFMUSP. ORCID: https://orcid.org/0000-0002-8408-0508. E-mail: alberto.meyer@hc.fm.usp.br.

4. Cirurgião e Coordenador Serviço de Transplante de Fígado do Departamento de Gastroenterologia do Hospital das Clínicas da Faculdade de Medicina da Universidade de São Paulo - HCFMUSP. ORCID: https://orcid.org/0000-0002-5162-138X. E-mail: wellingtonandraus@gmail.com.

Correspondence: Kayo Augusto de Almeida Medeiros. Av. Dr. Arnaldo, 455. Cerqueira César, São Paulo, SP. CEP: 01246-903. E-mail: kayo.medeiros@ fm.usp.br. 


\section{INTRODUCTION}

\section{Hepatic Cirrhosis}

Tepatic Cirrhosis (HC) is a disease characterized by different mechanisms that result in the formation of irreversible scars in the liver, making it harder for the organ to perform its normal functions. The main etiological factors are alcohol abuse, viral hepatitis and autoimmune diseases. In the last decade, there has been an increase of cases related to cryptogenic liver disease and non-alcoholic fatty liver disease $\mathrm{e}^{1,2}$.

In 2013, HC was the 13th major cause of death in the world, responsible for approximately 1 million deaths ${ }^{(2)}$. In Brazil, there were 853,751 hospital admissions attributed to $\mathrm{CH}$ in the period 2001 and 2010. Of the total deaths in the country in this same time frame, $\mathrm{CH}$ corresponds to the 8 th leading cause of death in the country. Despite the importance of $\mathrm{CH}$ in Brazil, there isn't more precise epidemiological data regarding this condition ${ }^{3,4}$.

The disease initially is characterized by an asymptomatic phase, followed by a symptomatic phase marked by the development of symptoms such as: ascites, jaundice, fatigue, pruritus, gastrointestinal hemorrhage, esophageal varices and portal hypertension ${ }^{(5)}$. With the worsening of liver functions, the appearance of these symptoms may accelerate the development of other complications such as renal worsening, hepatopulmonary syndrome and sepsis ${ }^{6,7}$. The complex drug treatment although not curative at all may contribute to symptom relief and control of $\mathrm{CH}$ complications ${ }^{8}$.

HC may progress to acute or chronic hepatic impairment, and in these cases the option of treatment is liver transplantation. Brazil is the country that most transplants in Latin America, occupying the third place in the world. Between 2005 and 2015, 14,817 liver transplants were performed in Brazil $^{9,10}$. According to data published by the Brazilian Association of Organ Transplantation (ABTO), in 2016 the country had 62 active staff and performed a total of 1880 transplants of liver. Presenting a list of 1331 active patients waiting for transplantation ${ }^{11}$.

Because it is a chronic disease, $\mathrm{HC}$ requires changes in the habits of the patient. Human behavior are shaped by the beliefs of each individual, these which will directly influence the decisions of the patient to follow the treatment or not. Beliefs are derived from different sources such as personal, family, social experiences ${ }^{12}$.

In this perspective, knowledge is one of the variables that will lead to a change in behavior towards illness, in addition to the time of diagnosis, family support, beliefs related to health and illness, among others, will also contribute to the management of the patient in the face of illness ${ }^{13}$. In the case of patients who require solid organ transplantation, the need for an educational process becomes even more relevant. In this case, the patient must learn how to administer the new medication that will be used for the rest of his life, in addition to adhering to changes in lifestyle ${ }^{14}$.

In view of the above, it is essential for the health professional to conceive the transmission of information as a relevant point of their work with the patient. Develop ways to make information accessible to the population in which it is being served. Low levels of schooling - poor patient literacy, for example, can interfere negatively with the prognosis of the disease, as the understanding of medical guidance is impaired, thereby increasing mortality rates, visits to emergency centers and readmissions ${ }^{15}$.

Thus, entering the population of the present study - the patients with HC and the importance of the health team to take into account the information transmitted, it is possible to mention a research developed with the objective of evaluating the patients' knowledge about the process of liver transplantation. The results demonstrate the difficulty that the teams encounter in communicating with the patient. The research was carried out with 62 candidates on a transplant list, with a mean score of 7.4 with a standard deviation of 2.5. Post-transplantation questions had the worst hit rates, $43 \%$ reported receiving information, and $77.4 \%$ did not think it was sufficient. Regarding the understanding of the disease and transplantation, $37.1 \%$ and $45.2 \%$, respectively, indicated insufficient understanding. Based on these results, the need to develop educational strategies capable of improving the understanding of the transplantation process is emphasized ${ }^{16}$.

As a basis for the studies cited for a good prognosis of treatment the patient needs to know his / her illness and the implications involved treatment. One strategy for accessing the patient's knowledge is through measuring instruments.

Some studies have developed and validated instruments aimed at understanding the patient's knowledge of his disease. In the national scope we can mention Padilha et al. ${ }^{17}$ who investigated beliefs and attitudes in valvopathic patients. The work of Bonin et al. ${ }^{18}$, constructed a questionnaire to measure the knowledge of the patient with heart failure. The research of Zulianello et al. ${ }^{19}$, who constructed and validated a psychometric scale to assess the knowledge of hypertensive patients. Maciel et al. ${ }^{20}$ developed a belief scale on mental illness. In addition, referring to international studies, we have Benhamou et al ${ }^{(14)}$ who developed and validated an instrument to evaluate fears and beliefs in patients with osteoarthritis of the knee. Siklosi et al. ${ }^{21}$ who developed and validated a questionnaire to evaluate patients' knowledge about Cystic Fibrosis. Bardazzi et al. ${ }^{21}$ validaram um questionário sobre a consciência dos pacientes com psoríase. Zschocke et al. ${ }^{23}$ 
validated a questionnaire on the conscience of patients with psoriasis. Zschocke et al. ${ }^{24}$ developed an instrument to evaluate the quality of life in patients with primary hyperparathyroidism.

The aforementioned researches had as objective the development of instruments aiming at a better understanding of the patient about his illness.

\section{Construction of research instruments}

The stages of construction of a measuring instrument can be presented as follows:

$1^{\text {st }}$ step - definition of the objectives of the instrument ${ }^{28}$;

$2^{\text {nd }}$ step - construction of items and response scales: items should not be chosen at random. The search in the literature, in national and international databases is the main resource used in the development of measurement instruments. Besides the construction of the items another relevant point is the choice of the method to obtain answers. The "likert scale" is the most used to survey opinions, attitudes and evaluations ${ }^{25,26}$;

$3^{\text {rd }}$ step - selection and organization of items: items should be organized in a logical manner to reduce the mental effort of the individual. The construction of a questionnaire should be formulated in such a way as to present questions respecting the principles of clarity, coherence and neutrality. The writing of the questions should use clear and comprehensible language, avoiding complex, ambiguous and too long questions ${ }^{25,27}$.

After having organized and structured the items the instrument needs to be tested for the hypothesis that the defined items adequately represent the domains of the construct. The procedure of choice for this purpose is content evaluation. The validity of content is a fundamental process in the development of an instrument. It is not represented statistically, which means that it is not expressed by a correlation coefficient but results from the judgment of different examining specialists. Because it is a subjective method, it is necessary to use other psychometric measures $^{28,29}$.

Still at this stage it is recommended that a quantitative analysis be done between the agreement of the evaluating (specialists) members. One way to perform this analysis is through the Content Validity Index (CVI). The CVI indices measure the proportion of experts who are in agreement on the items of the instrument. Allows you to analyze each item individually and subsequently the instrument as a whole. It is a widely used method in the health area $28,30,31$.

$4^{\text {th }}$-Pre-test: the objective is to evaluate whether all items are comprehensible to all members of the population to which the instrument is intended. At the end of this step the measuring instrument is ready to have its psychometric properties evaluated ${ }^{25}$.

\section{MATERIAL AND METHOD}

It is a cross-sectional study, which will include intentional and non-probablistic sample $t$.

The study was submitted to the "Comitê de Ética em Pesquisa da Instituição” (CAPPESQ), approved according to Research Protocol no. 15056. After approval, the process of development was divided into five stages, as following.

\section{Steps of the development process of the instrument}

\section{Step 1: Construction of the instrument}

The construction of the instrument was carried out based on an extensive bibliographical review, with relevant publications on the subject in the last 5 years.

The instrument was divided into 4: signs and symptoms, diagnosis, treatment and medication. The first version of the instrument had 15 questions in each of the topics, presenting a total of 60 questions. There is no consensus on the number of items that should contain a scale, however some authors point out that it is advisable for each dimension (category) to have between five and ten items ${ }^{33}$.

\section{Step 2: Instrument evaluation process}

A group of professionals was invited to participate in the evaluation process of the instrument, to verify the validity of the content. The requirement used in the selection of the specialists was: to act for at least 1 year with assistance from $\mathrm{CH}$ patients. At that stage, 5 health professionals from different areas (a nurse, a doctor, two psychologists and a social worker) participated in the evaluation process.

Criteria for instrument evaluation: content validity

Content validity is defined as a measure that evaluates whether the test (instrument) measures what it is intended to measure. That is, validity refers to an index of agreement between what it measures and what it proposes to measure ${ }^{34}$.

Quantitative Analysis: the content validity index (CVI) was the tool used. The calculation in this method is done through a "likert scale" of 4 ordinal points. According to the authors for the evaluation of the relevance of the item (question) the experts can choose 1- not clear, 2-unclear, 3 -quite clear, 4-very clear. The index score is calculated from the sum of items that have been marked by experts as " 3 " or " 4 ", dividing that sum by the total number of responses. Items that received 1 or 2 should be reviewed or deleted ${ }^{28}$.

The formula for evaluating each item can be described as follows: 
CVI= (Number of responses "3" or " 4 ") / (Total number of responses)

In this paper, it is emphasized that the "likert scale" used was 10 ordinal points. For each question, a scale was organized with values ranging from 1 to 10 , with 1 to 4 being the question considered confusing, 5 to 7 , the question is considered unclear, 8 to 10 the question is considered clear. It is possible to describe the IVC formula for the work as follows:

CVI= (Number of responses "8", "9" or "10") / (Total number of responses)

It is important to note that even with the variation of the "likert scale" in this work, there was no statistical change in the result of the evaluation of each item. The minimum agreement rate to maintain the question remains the same as described in the literature which indicates a minimum acceptable agreement of $0.80^{24,30}$. The result obtained from the CVI formula should be a value equal to or greater than 0.80 to maintain the question.

For each of the questions the response of each evaluator is evaluated. Responses with scores equal to or greater than 8 are retained. Responses with a value less than 8 are discarded. The final score of the question is the number of valid answers ( 8.9 or 10 - clear question) divided by the total number of answers and multiplied by 100 .

Qualitative Analysis: at the end of each question a space was left for the evaluators to make suggestions regarding the analysis of content, clarity and semantics of the question. The experts were able to assess the quality of the items, whether the questions were clear and whether the content was understandable.

\section{Step 3: Restructuring of the instrument}

The statistical results of the quantitative analysis added to the qualitative analysis generated the second version of the instrument. Some questions were discarded because they did not meet the established criteria, other questions were reworked and new questions were developed and included in the instrument. All changes were based on expert considerations.

The second version of the instrument presented 46 questions, the topics (signs and symptoms, diagnosis, treatment and medication) were kept. In the second version the drugs entered as a subtopic of the treatment category. It was decided to reduce the number of questions of all categories. Thus, each topic got 10 questions and the subtopics drugs with 6 questions.

\section{Step 4: Instrument reassessment process}

After the construction of the second version of the instrument, the experts who participated in the first round were contacted (via email) to participate again in the evaluation. After accepting, the second printed version of the instrument was delivered. At this stage, experts were asked to complete a form with their data and professional experiences.

The evaluation process, in this second stage was simpler. The questions that were re-elaborated passed only by quantitative analysis, using the same method - the Content Validity Index (CVI). In addition, the second version of the instrument had another "likert scale" (of 5 points) for quantitative analysis.

The new questions that were included, besides going through the quantitative analysis process described above, also had a space for suggestions and comments (semantic analysis).

\section{Step 5: Development of the final version of the} instrument

At the end of the second round, the corrections were considered appropriate. The questions of the instrument went through the steps proposed by the literature making the instrument adequate and reliable. The questions have undergone semantic changes according to the experts' suggestion, reaching scores equal to or greater than 8 .

The questions developed in this process will subsequently be transformed into an instrument used as a questionnaire with patients. There are different ways to build a quiz, they can be open, closed or mixed. In the present study, we opted for the development of a closed questionnaire, seeking the practicality, ease and speed of responses. The proposal is that the questionnaire becomes a possible tool to be used by different health professionals (doctors, nurses, psychologists, among others) who work in the care of $\mathrm{CH}$ patients.

The questions of the instrument that will be used with the patients will be measured through a "likert scale" of 5 points. The patient may choose an alternative response. The alternatives will be: totally disagree, partially disagree, do not know answer, partially agree, totally agree. The number of odd response alternatives allows one to place a neutral point in the middle of the scale ${ }^{26}$.

\section{RESULTS AND STATISTICAL ANALYSIS}

\section{First version of the instrument}

From the bibliographic review, 60 questions were constructed, as mentioned the questions were divided into blocks following the topics (signs and symptoms, diagnosis, treatment, medication). Each topic has 15 questions.

Experts analyzed each question individually using a 10-point "likert scale" to evaluate each question. The options of evaluation were: confusing question, question considered unclear, question considered clear. In addition, at the end of each question was a space for suggestions and comments. 
Medeiros KAA, et al. Development of an instrument to evaluate the knowledge that the patient.

\section{Evaluation of psychometric properties}

The results of the questions are described in the Tables 1- signs and symptoms, 2 - diagnosis, 3 - treatment, 4 medicines. For each topic we developed 15 questions, the evaluation was done by 5 experts, which resulted in a total of 75 responses $(15 \times 5=75)$ per topic.

When evaluating the whole instrument including the 75 responses of each topic, which leads to a total of 300 responses, a total of $12 \%$ of answers considered confusing (36/300), 17.7\% of answers considered little (53/300) and $70.3 \%$ of responses considered clear $(211 / 300)$.

Two tables by topics will be presented below. The first refers to the questions of the instrument and the second to the results of the expert evaluation

Table 1 - Signs and symptons: Questions presentation

\begin{tabular}{|c|c|}
\hline \multicolumn{2}{|r|}{ SIGNS AND SYMPTONS } \\
\hline Q1 & $\begin{array}{l}\text { Symptoms of liver cirrhosis are cured by changing lifestyle } \\
\text { habits }\end{array}$ \\
\hline Q2 & $\begin{array}{l}\text { Having no symptoms means that liver cirrhosis is not } \\
\text { considered severe }\end{array}$ \\
\hline Q3 & $\begin{array}{l}\text { Body itching, yellowing, ascites and encephalopathy are } \\
\text { some symptoms of liver cirrhosis }\end{array}$ \\
\hline Q4 & $\begin{array}{l}\text { Liver cirrhosis may cause malnutrition, leaving the patient } \\
\text { weak }\end{array}$ \\
\hline Q5 & $\begin{array}{l}\text { Patients may have a diagnosis of cirrhosis and have no } \\
\text { symptoms, ie have the disease compensated }\end{array}$ \\
\hline Q6 & $\begin{array}{l}\text { Ascites is a common complication of cirrhosis and is } \\
\text { characterized by the retention of fluid in the belly }\end{array}$ \\
\hline Q7 & $\begin{array}{l}\text { Hepatic cirrhosis, in some cases, presents complications } \\
\text { (esophageal varices, encephalopathy, ascites) that should } \\
\text { be treated as they may complicate further health status }\end{array}$ \\
\hline Q8 & $\begin{array}{l}\text { Following the nutritionist's dietary guidelines may aid in } \\
\text { the control of ascites and encephalopathy, complications } \\
\text { common in liver cirrhosis }\end{array}$ \\
\hline Q9 & $\begin{array}{l}\text { Hepatic encephalopathy present as symptoms: mental } \\
\text { confusion, disorientation, tremors in the hands, slurred } \\
\text { speech, slow movement, and in more severe cases can } \\
\text { lead to coma }\end{array}$ \\
\hline Q10 & $\begin{array}{l}\text { Liver cirrhosis may trigger symptoms of anxiety and } \\
\text { depression }\end{array}$ \\
\hline Q11 & $\begin{array}{l}\text { Hepatic encephalopathy can affect your ability to work and } \\
\text { drive and can cause car accident risks. }\end{array}$ \\
\hline Q12 & $\begin{array}{l}\text { When presenting symptoms of jaundice, that is the } \\
\text { yellowish, it means that the liver is regenerating and } \\
\text { showing signs of improvement }\end{array}$ \\
\hline Q13 & $\begin{array}{l}\text { Patients with hepatic encephalopathy should be monitored } \\
\text { on leaving home. }\end{array}$ \\
\hline Q14 & $\begin{array}{l}\text { The liver with cirrhosis releases toxic substances that can } \\
\text { attack the cardiovascular system causing cardiac arrest }\end{array}$ \\
\hline Q15 & $\begin{array}{l}\text { The patient presenting with a hepatic encephalopathy crisis } \\
\text { should seek help considering that the condition may worsen } \\
\text { rapidly and become an emergency condition }\end{array}$ \\
\hline
\end{tabular}

Table 2 - Signs and symptons: Validation of content. According to experts' in the topic Signs and Symptoms presented as answers: $5.3 \%$ considered confusing (4/75), 16\% considered unclear $(12 / 75)$ and $78.7 \%(59 / 75)$ considered clear

\begin{tabular}{c|c|c|c}
\hline \multicolumn{3}{c}{ SIGNS AND SYMPTONS } \\
\hline & $\begin{array}{c}\text { Confusing } \\
(\mathbf{0}, \mathbf{1}, \mathbf{3}, \mathbf{3}) \\
\text { N (\%) }\end{array}$ & $\begin{array}{c}\text { Unclear } \\
\mathbf{( 5 , 6 , 7 )}\end{array}$ & $\begin{array}{c}\text { Clear } \\
\mathbf{( 8 , 9}, \mathbf{1 0})\end{array}$ \\
\hline Q1 & $0(0 \%)$ & $2(40 \%)$ & $3(60 \%)$ \\
\hline Q2 & $0(0 \%)$ & $0(0 \%)$ & $5(100 \%)$ \\
\hline Q3 & $0(0 \%)$ & $1(20 \%)$ & $4(80 \%)$ \\
\hline Q4 & $0(0 \%)$ & $0(0 \%)$ & $5(100 \%)$ \\
\hline Q5 & $0(0 \%)$ & $2(40 \%)$ & $3(60 \%)$ \\
\hline Q6 & $0(0 \%)$ & $1(20 \%)$ & $4(80 \%)$ \\
\hline Q7 & $0(0 \%)$ & $1(20 \%)$ & $4(80 \%)$ \\
\hline Q8 & $0(0 \%)$ & $2(40 \%)$ & $3(60 \%)$ \\
\hline Q9 & $0(0 \%)$ & $0(0 \%)$ & $5(100 \%)$ \\
\hline Q10 & $0(0 \%)$ & $2(40 \%)$ & $3(60 \%)$ \\
\hline Q11 & $1(20 \%)$ & $0(0 \%)$ & $4(80 \%)$ \\
\hline Q12 & $2(40 \%)$ & $0(0 \%)$ & $3(60 \%)$ \\
\hline Q13 & $0(0 \%)$ & $0(0 \%)$ & $5(100 \%)$ \\
\hline Q14 & $0(0 \%)$ & $1(20 \%)$ & $4(80 \%)$ \\
\hline
\end{tabular}

Based on the literature criteria, questions with scores lower than 0.80 or represented in the tables by $80 \%$ were excluded. In the case of the topic Signs and Symptoms a Q1, Q5, Q8, Q10, Q12. Thus, of the 15 questions only 5 were discarded, representing $33.3 \%$ of questions.

Although Q14 and Q15 reached an average of $80 \%$, they were excluded based on the specialists' (semantic analysis) assignments that the instrument was highly favoring the symptom of hepatic encephalopathy and disregarding other symptoms also common in $\mathrm{CH}$. It was decided to leave the instrument with fewer questions portraying encephalopathy. 
Table 3 - Diagnosis: Questions presentation.

\section{DIAGNOSIS}

\begin{tabular}{|c|c|}
\hline Q1 & Liver cirrhosis is a disease that attacks the liver \\
\hline Q2 & $\begin{array}{l}\text { Hepatic cirrhosis can be caused by different causes, } \\
\text { for example, hepatitis, alcohol and autoimmune } \\
\text { diseases, among other causes }\end{array}$ \\
\hline Q3 & $\begin{array}{l}\text { Liver cirrhosis is a disease that affects the elderly due } \\
\text { to weakened liver function }\end{array}$ \\
\hline Q4 & $\begin{array}{l}\text { The diagnosis of liver cirrhosis does not require a } \\
\text { change in eating habits }\end{array}$ \\
\hline Q5 & $\begin{array}{l}\text { Liver cirrhosis is considered a serious disease and if } \\
\text { left untreated can lead to death }\end{array}$ \\
\hline Q6 & $\begin{array}{l}\text { Liver cirrhosis allows moderate consumption of } \\
\text { alcohol }\end{array}$ \\
\hline Q7 & $\begin{array}{l}\text { Liver biopsy is one of the tests used for the diagnosis } \\
\text { of liver cirrhosis }\end{array}$ \\
\hline Q8 & $\begin{array}{l}\text { The diagnosis of liver cirrhosis forbids the practice of } \\
\text { physical exercises as they may impair the functioning } \\
\text { of the liver }\end{array}$ \\
\hline Q9 & $\begin{array}{l}\text { The only cause of liver cirrhosis is excessive alcohol } \\
\text { consumption }\end{array}$ \\
\hline Q10 & Liver cirrhosis is a contagious disease \\
\hline Q11 & $\begin{array}{l}\text { Liver cirrhosis is considered a chronic disease, ie it } \\
\text { will accompany the individual throughout life }\end{array}$ \\
\hline Q12 & $\begin{array}{l}\text { The sick liver in liver cirrhosis may impair the } \\
\text { functioning of other organs }\end{array}$ \\
\hline Q13 & $\begin{array}{l}\text { The diagnosis of liver cirrhosis makes continuous } \\
\text { medical follow-up essential for early detection of } \\
\text { possible complications of the disease }\end{array}$ \\
\hline Q14 & $\begin{array}{l}\text { Hepatic cirrhosis is caused by the exaggeration of hot } \\
\text { beverages ingested daily }\end{array}$ \\
\hline Q15 & $\begin{array}{l}\text { Hepatocarcinoma (liver cancer) is a disease that may } \\
\text { be present along with the diagnosis of liver cirrhosis }\end{array}$ \\
\hline
\end{tabular}

These 15 questions were submitted to the same analysis showed in Table 2, where based on the evaluation of the specialists, the instrument in the diagnosis topic presented $16 \%$ of responses considered confusing (12/75), $21.3 \%$ of responses considered unclear (16/75) and $62.7 \%$ of answers considered clear. (47/75).

Questions with scores of less than $80 \%$ were excluded for the topic Diagnostic Q3, Q4, Q5 Q7, Q8, Q12, Q14. Therefore, of the 15 questions 7 were discarded, representing $46.6 \%$ of questions.
Table 4 - Treatment: Questions presentation

\section{TREATMENT}

\begin{tabular}{|c|c|}
\hline Q1 & $\begin{array}{l}\text { In cases of severe cirrhosis, the only form of treatment } \\
\text { is transplantation }\end{array}$ \\
\hline Q2 & $\begin{array}{l}\text { Transplantation is characterized by the exchange of } \\
\text { one sick liver for another healthy one }\end{array}$ \\
\hline Q3 & $\begin{array}{l}\text { Transplantation is considered a low complexity } \\
\text { surgery }\end{array}$ \\
\hline Q4 & $\begin{array}{l}\text { Some foods can harm the patient with liver cirrhosis } \\
\text { and need to be avoided, so it is necessary to follow } \\
\text { up with a nutritionist }\end{array}$ \\
\hline Q5 & $\begin{array}{l}\text { When diagnosing liver cirrhosis, it is necessary to } \\
\text { organize with a social support network to assist } \\
\text { with hospital visits, medication use and care during } \\
\text { treatment }\end{array}$ \\
\hline Q6 & $\begin{array}{l}\text { When entering the transplant list it is necessary to } \\
\text { continue in multiprofessional follow-up (nursing, } \\
\text { nutrition, psychology, social work) }\end{array}$ \\
\hline Q7 & $\begin{array}{l}\text { The transplant list works according to the order of } \\
\text { arrival, that is, patients enrolled by first receive the } \\
\text { organ before the second, and thus consecutively }\end{array}$ \\
\hline Q8 & $\begin{array}{l}\text { Rejection of the new organ may occur after } \\
\text { transplantation, and this means the possibility of a } \\
\text { retransplantation }\end{array}$ \\
\hline Q9 & $\begin{array}{l}\text { When entering the transplant queue, a waiting period } \\
\text { begins for the organ. This period can be quite stressful, } \\
\text { leading to symptoms of anxiety and depression that } \\
\text { must be followed by psychiatrists and psychologists }\end{array}$ \\
\hline Q10 & $\begin{array}{l}\text { After the transplant, no medical follow-up or hospital } \\
\text { will be necessary because the disease will be cured }\end{array}$ \\
\hline Q11 & $\begin{array}{l}\text { Life habits (work, physical activities and feeding) need } \\
\text { to be adapted after transplantation }\end{array}$ \\
\hline Q12 & $\begin{array}{l}\text { To receive the appropriate care, after the transplant } \\
\text { surgery the patient goes to the ICU and later to the } \\
\text { infirmary }\end{array}$ \\
\hline Q13 & $\begin{array}{l}\text { The MELD of the patient is one of the criteria } \\
\text { for allocation in the transplant queue (result of an } \\
\text { examination) }\end{array}$ \\
\hline Q14 & $\begin{array}{l}\text { Once enrolled in the transplant queue it can no longer } \\
\text { be removed }\end{array}$ \\
\hline Q15 & $\begin{array}{l}\text { A high MELD value indicates a greater severity of } \\
\text { the disease }\end{array}$ \\
\hline
\end{tabular}

Table 4 was submitted to the evaluation of the specialists, the instrument in the topic Treatment received the following answers: $16 \%$ were considered confusing $(12 / 75), 16 \%$ considered unclear $(12 / 75)$, and $68 \%$ considered clear $(51 / 75)$.

Questions with scores lower than $80 \%$ were excluded for the topic Treatment Q1, Q3, Q7, Q8, Q11, Q13 Q14. Therefore, of the 15 questions 7 were discarded, representing $46.6 \%$ of questions. Q15 changed to the diagnostic topic. 
Table 5 - Medication: Questions presentation

\section{MEDICATION}

\begin{tabular}{|c|c|}
\hline Q1 & $\begin{array}{l}\text { Continued use of medications may cause other (negative) } \\
\text { health effects }\end{array}$ \\
\hline Q2 & $\begin{array}{l}\text { Medications used to treat liver cirrhosis cause sexual } \\
\text { impotence }\end{array}$ \\
\hline Q3 & $\begin{array}{l}\text { The medications prescribed by the doctor are exaggerated } \\
\text { and cause undesirable side effects }\end{array}$ \\
\hline Q4 & $\begin{array}{l}\text { Lactulone is one of the main medicines used in the } \\
\text { treatment of hepatic encephalopathy }\end{array}$ \\
\hline Q5 & $\begin{array}{l}\text { The medications prescribed by the doctor are not for } \\
\text { curing cirrhosis but for treating and controlling the } \\
\text { symptoms of the disease }\end{array}$ \\
\hline Q6 & $\begin{array}{l}\text { Before taking any medication it is essential to talk to the } \\
\text { doctor because some medicines should be avoided by } \\
\text { further damaging the sick liver }\end{array}$ \\
\hline Q7 & $\begin{array}{l}\text { Drug treatment can cure liver cirrhosis and no longer } \\
\text { require transplantation }\end{array}$ \\
\hline Q8 & $\begin{array}{l}\text { It is important that the medicines are ingested according } \\
\text { to the medical orientation, following the exact dosage } \\
\text { and times }\end{array}$ \\
\hline Q9 & $\begin{array}{l}\text { After transplantation, I must use the medication } \\
\text { (immunosuppressive drugs) for the rest of my life }\end{array}$ \\
\hline Q10 & $\begin{array}{l}\text { Immunosuppressive drugs lower the body's immunity } \\
\text { which leads to a greater likelihood of acquiring other } \\
\text { diseases (for example, colds), so it is necessary to take } \\
\text { greater care with health }\end{array}$ \\
\hline Q11 & $\begin{array}{l}\text { The transplant aims to cure liver disease, which means } \\
\text { that after it is done it will no longer be necessary to use } \\
\text { any medication }\end{array}$ \\
\hline Q12 & $\begin{array}{l}\text { It is possible to stay without taking the immunosuppressive } \\
\text { drugs for a maximum of one week without causing } \\
\text { damage to the new transplanted organ }\end{array}$ \\
\hline Q13 & $\begin{array}{l}\text { When presenting an undesirable side effect of } \\
\text { immunosuppressants I must inform the doctor before } \\
\text { taking any medication }\end{array}$ \\
\hline Q14 & $\begin{array}{l}\text { Immunosuppressive drugs are very expensive, which } \\
\text { makes it difficult to use them according to medical } \\
\text { orientation }\end{array}$ \\
\hline Q15 & $\begin{array}{l}\text { Adherence to drug treatment can be facilitated with } \\
\text { family support, which can assist with timing and correct } \\
\text { use of the drug, for example. }\end{array}$ \\
\hline
\end{tabular}

Table 5 - In the topic Medications the expert evaluation presented $10.7 \%$ of answers considered confusing $(8 / 75), 17.3 \%$ of responses considered unclear $(13 / 75)$ and $72 \%$ of responses considered clear $(54 / 75)$..

Questions with scores below 80\% were excluded for the topic Medications Q1, Q3, Q4, Q6, Q7, Q10, Q14. Therefore, of the 15 questions 7 were discarded, representing $46.6 \%$ of questions.

Q12 and Q13 were discarded despite having obtained an average of $80 \%$, the justification for excluding these questions is related to a repetition of this content immunosuppressive drugs on several questions. Given that the proposal is also to make the instrument less extensive and put the topic medication as a subcategory of the treatment.

The next step was related to the semantic and content analysis performed by the evaluators. Based on the various comments of the semantic analysis, the suggested changes were made and the questions were restructured.

The semantic analysis of the evaluators presented almost unanimously the suggestion to change the word hepatic cirrhosis to cirrhosis in the liver. From a general perspective it can be observed that the experts put as suggestions to make use of a simpler and accessible language to the target audience. The scores were relevant and accepted in the restructuring of the instrument for the 2nd version.

Suggestions for subjects or contents that were not addressed in the first version of the instrument and that were considered relevant by the experts in each topic will be presented below.

Table 6 - General comments on topics: suggestion or addition of content

\begin{tabular}{|c|c|}
\hline Topics & Relevant contents to be addressed \\
\hline $\begin{array}{l}\text { Signs and } \\
\text { Symptons }\end{array}$ & $\begin{array}{l}\text { Alert to the stool darkening symptom; } \\
\text { Address the symptom of esophageal varices; } \\
\text { Presence of memory problems, tiredness } \\
\text { and depressive symptoms; } \\
\text { Enceph a lop athy with drow siness, } \\
\text { forgetfulness, aggressive behavior. }\end{array}$ \\
\hline Diagnosis & $\begin{array}{l}\text { Obesity as a cause associated with cirrhosis; } \\
\text { Diagnosis performed in the decompensated } \\
\text { phase; } \\
\text { Aspects of illness for being silent; } \\
\text { Importance of early diagnosis. }\end{array}$ \\
\hline Treatment & $\begin{array}{l}\text { Take focus only from transplantation as } \\
\text { a treatment, including other possibilities } \\
\text { of treatment, medicinal, nutritional, } \\
\text { psychological; } \\
\text { Differentiated care requiring the pre- and } \\
\text { post-transplantation; } \\
\text { Relevance of follow-up during treatment to } \\
\text { monitor symptoms; } \\
\text { Address need for support network, family, } \\
\text { spouse. }\end{array}$ \\
\hline Medications & $\begin{array}{l}\text { Address different actions of medications, } \\
\text { preventive, improvement of symptoms, etc. }\end{array}$ \\
\hline
\end{tabular}

An analysis of the contents suggested by the specialists was carried out. (in bold in the table above) have become questions in the second version of the instrument. 
The very specific contents suggested within the topics were discarded in the production and restructuring of the questions, since it was understood that contemplating very specific questions could make the instrument very long and the objective would be to lose a broad view of the patient's knowledge.

\section{Second version of the instrument}

The second version of the instrument had 46 questions, distributed in the topics signs and symptoms, diagnosis, treatment and subcategory medicines.

\section{Evaluation of psychometric properties}

Each category presents 10 questions +6 questions of the subcategory medication. A total of 50 responses were obtained by category and 30 responses for the medication subcategory.

The tables, with the questions and the result of the evaluation of the specialists are shown below.

Table $7-2^{\text {nd }}$ version - Signs and symptons: questions presentation with CVI

\begin{tabular}{|c|c|c|}
\hline \multicolumn{2}{|r|}{ SIGNS AND SYMPTONS } & CVI \\
\hline Q1 & $\begin{array}{l}\text { Cirrhosis of the liver (hepatic) can cause malnutrition } \\
\text { and leave the patient weak }\end{array}$ & 60 \\
\hline Q2 & $\begin{array}{l}\text { Body itching, yellowing of the skin, watery belly, } \\
\text { mental confusion (hepatic encephalopathy), } \\
\text { esophageal varices are some symptoms of cirrhosis } \\
\text { in the liver (hepatic) }\end{array}$ & 100 \\
\hline Q3 & $\begin{array}{l}\text { Having no symptoms means that cirrhosis in the liver } \\
\text { (liver) is not in a severe stage }\end{array}$ & 100 \\
\hline Q4 & $\begin{array}{l}\text { The belly of water (ascites) is a common complication } \\
\text { of cirrhosis in the liver (hepatic) and is characterized } \\
\text { by the accumulation of fluid in the belly }\end{array}$ & 100 \\
\hline Q5 & $\begin{array}{l}\text { Esophageal varices are rare complications in } \\
\text { cirrhosis of the liver (hepatic) }\end{array}$ & 80 \\
\hline Q6 & $\begin{array}{l}\text { Cirrhosis of the liver (hepatic), in some cases, } \\
\text { presents complications (esophageal varices, mental } \\
\text { confusion, belly of water) that must be treated and } \\
\text { accompanied by the doctor to avoid worsening of } \\
\text { the state of health }\end{array}$ & 100 \\
\hline Q7 & $\begin{array}{l}\text { The symptom of fatigue is not a complication of } \\
\text { cirrhosis in the liver (hepatic), fatigue is caused by } \\
\text { severe depression }\end{array}$ & 100 \\
\hline Q8 & $\begin{array}{l}\text { Hepatic encephalopathy presents as signs: mental } \\
\text { confusion, disorientation, tremors in the hands, } \\
\text { slurred speech, slow movements, loss of memory, } \\
\text { and in more severe cases can lead to coma }\end{array}$ & 100 \\
\hline Q9 & $\begin{array}{l}\text { The liver with liver cirrhosis releases toxic } \\
\text { substances that can attack the heart and cause } \\
\text { cardiac arrest }\end{array}$ & 100 \\
\hline Q10 & $\begin{array}{l}\text { Patients who present hepatic encephalopathy attacks } \\
\text { as signs of mental confusion, disorientation, slow } \\
\text { movements, etc. should always go out accompanied }\end{array}$ & 80 \\
\hline
\end{tabular}

In the modification the Q3 have a worsening of the CVI. The other questions were the same.
Table $8-2^{\text {nd }}$ version- Diagnosis: questions presentation with CVI

\begin{tabular}{|c|c|c|}
\hline \multicolumn{2}{|r|}{ DIAGNOSIS } & CVI \\
\hline Q1 & $\begin{array}{l}\text { Cirrhosis of the liver is characterized by liver damage } \\
\text { that causes the organ to lose its functions }\end{array}$ & 100 \\
\hline Q2 & $\begin{array}{l}\text { The only cause of cirrhosis in the liver (liver) is alcohol } \\
\text { consumption }\end{array}$ & 60 \\
\hline Q3 & $\begin{array}{l}\text { It is possible to have cirrhosis in the liver (liver) and } \\
\text { hepatocarcinoma (liver cancer) at the same time }\end{array}$ & 100 \\
\hline Q4 & $\begin{array}{l}\text { Liver cirrhosis (hepatic) disease requires continuous } \\
\text { medical follow-up to assess the path of the disease }\end{array}$ & 100 \\
\hline Q5 & $\begin{array}{l}\text { Cirrhosis of the liver (liver) can be caused by different } \\
\text { causes, for example: hepatitis B or C, alcohol, liver fat } \\
\text { and autoimmune diseases }\end{array}$ & 100 \\
\hline Q6 & $\begin{array}{l}\text { Cirrhosis of the liver (hepatic) is a contagious disease } \\
\text { transmitted by the bite of a mosquito }\end{array}$ & 80 \\
\hline Q7 & $\begin{array}{l}\text { Liver cirrhosis is often discovered when the patient } \\
\text { has complications of the disease: watery belly, mental } \\
\text { confusion (encephalopathy), varicose veins of the } \\
\text { esophagus, yellowing of the skin }\end{array}$ & 100 \\
\hline Q8 & $\begin{array}{l}\text { Liver cirrhosis (hepatic) allows moderate alcohol } \\
\text { consumption }\end{array}$ & 100 \\
\hline Q9 & $\begin{array}{l}\text { Liver cirrhosis is considered a chronic disease, ie it will } \\
\text { accompany the individual throughout life }\end{array}$ & 100 \\
\hline Q10 & $\begin{array}{l}\text { A high MELD value indicates a greater severity of } \\
\text { the disease }\end{array}$ & 80 \\
\hline
\end{tabular}

We observed that in the second CVI there was a worsening in Q2, and despite the worsening the question was maintained. There was an improvement in Q1, Q6, Q9 and Q10. The other questions were the same.

Table $9-2^{\text {nd }}$ version - Treatment: questions presentation

\begin{tabular}{|c|c|c|}
\hline \multicolumn{2}{|r|}{ TREATMENT } & \multirow{2}{*}{$\begin{array}{c}\text { CVI } \\
80\end{array}$} \\
\hline Q1 & $\begin{array}{l}\text { The treatment of cirrhosis in the liver (hepatic) requires } \\
\text { only medical monitoring }\end{array}$ & \\
\hline Q2 & $\begin{array}{l}\text { When transplantation is indicated as a treatment for } \\
\text { cirrhosis in the liver (lhepatic), it is necessary to follow } \\
\text { the professionals (doctors, nurses, psychologists, } \\
\text { nutritionists, social workers) both in the pre-transplant } \\
\text { period and in the post-transplant period. }\end{array}$ & 80 \\
\hline Q3 & $\begin{array}{l}\text { Nutritionists' dietary guidelines are not indicated in the } \\
\text { treatment of cirrhosis in the liver (hepatic), as no food } \\
\text { can aggravate symptoms and illness }\end{array}$ & 100 \\
\hline Q4 & $\begin{array}{l}\text { Liver transplantation is surgery in which the sick liver } \\
\text { (with cirrhosis) is replaced by a healthy liver }\end{array}$ & 100 \\
\hline Q5 & $\begin{array}{l}\text { When entering the liver (hepatic) transplant queue it is } \\
\text { necessary to undergo evaluations and follow up with } \\
\text { several professionals, such as nurses, nutritionists, } \\
\text { psychologists, social workers, etc. }\end{array}$ & 100 \\
\hline Q6 & $\begin{array}{l}\text { The treatment of cirrhosis in the liver requires a social } \\
\text { support network, ie help from friends and / or family } \\
\text { members for hospital visits, medication use and tasks } \\
\text { of daily living }\end{array}$ & 100 \\
\hline Q7 & $\begin{array}{l}\text { After enrollment in the liver (hepatic) transplant queue, } \\
\text { waiting for the organ can be stressful, in this period it } \\
\text { may arise from symptoms of anxiety and depression } \\
\text { that need to be followed up by psychiatrists and } \\
\text { psychologists }\end{array}$ & 80 \\
\hline Q8 & $\begin{array}{l}\text { In order to receive adequate care after transplant } \\
\text { surgery in the liver (hepatic) the patient stays an } \\
\text { interned period in the ward, and only in severe cases } \\
\text { or complications can he go to the ICU }\end{array}$ & 100 \\
\hline Q9 & $\begin{array}{l}\text { After recovery from liver (liver) transplant surgery no } \\
\text { further medical follow-up is needed considering that } \\
\text { the disease has been cured }\end{array}$ & 80 \\
\hline Q10 & $\begin{array}{l}\text { The patient may have different emotional reactions } \\
\text { (fears, anxieties, sadness, restlessness) during the } \\
\text { treatment of cirrhosis in the liver (liver), in the period } \\
\text { before and after transplantation. }\end{array}$ & 80 \\
\hline
\end{tabular}


In the modification there was worsening of the Q8 and in Q5, Q6, and Q9 there was an improvement. The other questions were the same.

Table 10 - $2^{\text {nd }}$ version - Medications: questions presentation

\begin{tabular}{|c|c|c|}
\hline \multicolumn{2}{|r|}{ MEDICATIONS } & CVI \\
\hline Q1 & $\begin{array}{l}\text { Medications used to treat liver cirrhosis (hepatic) } \\
\text { cause sexual impotence }\end{array}$ & 80 \\
\hline Q2 & $\begin{array}{l}\text { The medicines are not to cure cirrhosis in the } \\
\text { liver (lhepatic) but to control the symptoms of } \\
\text { the disease }\end{array}$ & 100 \\
\hline Q3 & $\begin{array}{l}\text { It is important that medications are taken } \\
\text { according to medical advice, following dosages } \\
\text { and times }\end{array}$ & 100 \\
\hline Q4 & $\begin{array}{l}\text { The goal of the transplant is to cure cirrhosis of } \\
\text { the liver, which means that after it is done it will } \\
\text { no longer be necessary to use any medication }\end{array}$ & 100 \\
\hline Q5 & $\begin{array}{l}\text { Adherence to drug treatment can be facilitated } \\
\text { with family support, which can assist with timing } \\
\text { and correct use of the drug, for example. }\end{array}$ & 100 \\
\hline Q6 & $\begin{array}{l}\text { After transplantation I should use the medication } \\
\text { against rejection (immunosuppressive drugs) for } \\
\text { the rest of my life }\end{array}$ & 100 \\
\hline
\end{tabular}

\section{Qualitative analysis of the instrument}

In the second version of the instrument, spaces were left for specialists to suggestions and comments on the semantic analysis of the questions. It should be noted that only added questions had spaces for writing.

The experts have not made any semantic consideration that has been judged the second round of

\section{REFERENCES}

1. Saberifiroozi M. Improving quality of care in patients with liver cirrhosis. Middle East J Dig Dis. 2017;9(4):189-200. doi: 10.15171/mejdd.2017.73.

2. MuirAJ.Understanding the complexities of cirrhosis. Clin Ther. 2015;37(8):1822-36. doi: 10.1016/j.clinthera.2015.05.507.

3. Carvalho JR de, Villela-Nogueira CA, Perez RM, Portugal FB, Flor LS, Campos MR, et al. Burden of chronic viral hepatitis and liver cirrhosis in Brazil - The Brazilian Global Burden of Disease Study. Ann Hepatol. 2017;16(6):893-900. doi: 10.5604/01.3001.0010.5280.

4. Nader LA, Mattos AA, Bastos GA. Burden of liver disease in Brazil. Liver Int. 2014;34(6):844-9. doi: 10.1111/liv.12470.

5. D'Amico G, Garcia-Tsao G, Pagliaro L. Natural history and prognostic indicators of survival in cirrhosis: a systematic review of 118 studies. J Hepatol. 2006;44(1):217-31. https:// doi.org/10.1016/j.jhep.2005.10.013.

6. Liu A, Perumpail RB, Kumari R, Younossi ZM, Wong RJ, Ahmed A. Advances in cirrhosis: optimizing the management of hepatic encephalopathy. World J Hepatol. 2015;7(29):28719. doi: 10.4254/wjh.v7.i29.2871. evaluation of the instrument changes in the questions. Thus, in this qualitative analysis, there are no results.

\section{Quantitative analysis of the instrument}

This second analysis was added only in the second version of the instrument. The objective was to evaluate some specific criteria of the instrument, if the text was: clear, objective, adapting to the context, the Brazilian culture and the evaluated population.

The results were analyzed through the CVI, maintaining the standard of the literature acceptance criterion equal to or greater than 80 . In the instrument need to have at least 4 of 5 specialists responding on the likert 4 or 5 scale to accepted.

All questions were adequate in all criteria, except for Q3 of "signs and symptons" in clear category and treatment's Q1 in adapting to the context.

\section{CONCLUSIONS}

The development of the instrument followed the steps described in literature. Each question put forward went through an extensive evaluation process and the suggestion of the evaluators allowed to restructure the questions making them clearer and more relevant to the proposal of the instrument. Qualitative and quantitative analyzes were performed, following the suggested psychometric standards for content validity, which made the instrument adequate and reliable.

Based on the objectives of this study, it can be said that it was possible to achieve satisfactorily the proposal of the construction of the instrument.-

7. Andraus W, Paoletti B, Pinheiro R, Bitencourt F, Farias C, D'Albuquerque L. Avaliação da qualidade de vida em pacientes cirróticos com hérnia da parede abdominal. ABCD Arq Bras Cir Dig. 2009;22(4):222-5. http://dx.doi. org/10.1590/S0102-67202009000400008.

8. Hayward KL, Valery PC, Martin JH, Karmakar A, Patel PJ, Horsfall LU, et al. Medication beliefs predict medication adherence in ambulatory patients with decompensated cirrhosis. World J Gastroenterol. 2017;23(40):7321-31. doi: 10.3748/wjg.v23.i40.7321.

9. Aguiar MIF de, Braga VAB, Almeida PC de, Garcia JHP, Lima CA de. Gravidade da doença hepática e qualidade de vida no transplante de fígado. Acta Paul Enferm. 2016;29(1):107-14. http://dx.doi.org/10.1590/1982-0194201600015.

10. Bittencourt PL, Farias AQ, Couto CA. Liver transplantation in Brazil. Liver Transplant. 2016;22(9):1254-8. doi: 10.1002/ 1t.24487.

11. Associação Brasileira de Transplante de Órgãos (ABTO). Dimensionamento dos transplantes no Brasil e em cada estado (2009-2016). RBT. 2016;22(4):1-89. Disponível em: http://www.abto.org.br/abtov03/upload/file/rbt/2016/ rbt2016-leitura.pdf 
Medeiros KAA, et al. Development of an instrument to evaluate the knowledge that the patient.

12. Benhamou M, Baron G, Dalichampt M, Boutron I, Alami $\mathrm{S}$, Rannou F, et al. Development and Validation of a Questionnaire Assessing Fears and Beliefs of Patients with Knee Osteoarthritis: The Knee Osteoarthritis Fears and Beliefs Questionnaire (KOFBeQ). PLoS One. 2013;8(1):e53886. doi: 10.1371/journal.pone.0053886.

13. Fernanda F, Rodrigues L, Antônio M, Regina C, Teixeira DS, Gonela JT, et al. Relationship between knowledge, attitude, education and duration of disease in individuals with diabetes mellitus. Acta Paul Enferm. 2012;25(2):284-90. http://dx.doi. org/10.1590/S0103-21002012000200020.

14. Dal Sasso Mendes K, Silva Junior OC, Ziviani LC, Rossin FM, Zago MMF, Galvão MC. Intervenção educativa para candidatos ao transplante de fígado. RLAE Rev Latino-Amer Enfermagen. 2013;21(1):1-7. doi: https://doi.org/10.1590/ S0104-11692013000100018.

15. Wright JP, Edwards GC, Goggins K, Tiwari V, Maiga A, Moses K, et al. Association of health literacy with postoperative outcomes in patients undergoing major abdominal surgery. JAMA Surg. 2017;2391(2):137-42. doi: 10.1001/jamasurg.2017.3832.

16. Oliveira PC de, Paglione HB, Mucci S, Silva VS e, Schirmer $\mathrm{J}$, Roza B de A. Avaliação do conhecimento dos candidatos a transplante de fígado. Rev Enferm da UFSM. 2017;6(4):529. doi: http://dx.doi.org/10.5902/2179769223175.

17. Padilha KM, Gallani MCBJ, Colombo RCR. Desenvolvimento de instrumento de medida de crenças e atitudes de pacientes valvopatas. Rev Latino-Amer Enfermagem. 2004;12(3):4539. http://dx.doi.org/10.1590/S0104-11692004000300002.

18. Bonin CDB. Construção e validação do questionário de conhecimentos da doença para pacientes com insuficiência cardíaca [dissertação]. Florianópolis: Universidade do Estado de Santa Catarina; 2013. Disponível em: http://tede.udesc.br/ handle/handle/259.

19. Zulianello R, Decker C, Bonin B, Ten E, Martins C, Junior MP, et al. Construção e validação psicométrica do HIPER-Q para avaliar o conhecimento de pacientes hipertensos em reabilitação cardíaca. Arq Bras Cardiol. 2017. Ahead of print. doi: $10.5935 /$ abc. 20170183 .

20. Maciel SC, Pereira CR, Lima TJS, Souza LEC. Desenvolvimento e validação da escala de crenças sobre a doença mental. Psicol Reflex Crit. 2015;28(3):463-73. http:// dx.doi.org/10.1590/1678-7153.201528305.

21. Siklosi KR, Gallagher CG, Mckone EF. Development, validation, and implementation of a questionnaire assessing disease knowledge and understanding in adult cystic fibrosis patients. J Cyst Fibros. 2010;9:400-5. doi: 10.1016/j. jef.2010.07.001.

22. Bardazzi F, Amerio P, Amoruso G, Campanati A, Conti A, Simone CDE, et al. Investigating psoriasis awareness among patients in Italy: validation of a questionnaire. Eur Rev Med Pharmacol Sci. 2014;3435-52. Available from: https://www. europeanreview.org/wp/wp-content/uploads/3435-3452.pdf.
23. Zschocke I, Mrowietz U, Lotzin A. Assessing adherence factors in patients under topical treatment: development of the Topical Therapy Adherence Questionnaire (TTAQ). Arch Dermatol Res. 2014;306:287-97. doi: 10.1007/s00403-0141446-x.

24. Webb SM, Puig-domingo M, Villabona C, Muñoz-torres M, Farrerons J, Badia X. Development of a new tool for assessing health-related quality of life in patients with primary hyperparathyroidism. Heal Qual Live Outcomes. 2013;11(97):1-8. doi: 10.1186/1477-7525-11-97.

25. Coluci MZO, Alexandre NMC, Milani D. Construção de instrumentos de medida na área da saúde. Cien Saude Coletiva. 2015;20(3):925-36. http://dx.doi.org/10.1590/141381232015203.04332013

26. Gunther H. Como elaborar um questionário. Lab Psicol Ambient. 2003;(1):1-35.

27. Meyer ALM, Teixeira MG, Almeida MG de, Kiss DR, Nahas SC, Cecconello I. Quality of life in the late followup of ulcerative colitis patients submitted to restorative proctocolectomy with sphincter preservation over ten years ago. Clinics. 2009;64(9):877-83. doi: 10.1590/S180759322009000900008

28. Alexandre NMC, Coluci MZO. Validade de conteúdo nos processos de construção e adaptação de instrumentos de medidas. Cien Saude Coletiva. 2011;16(7):3061-8. http:// dx.doi.org/10.1590/S1413-81232011000800006.

29. Raymundo VP. Construção e validação de instrumentos: um desafio para a psicolinguística. Let Hoje. 2009;44(3):8693. Disponível em: http://revistaseletronicas.pucrs.br/ ojs/index.php/\%EE $\% 80 \% 80$ fale $\%$ EE $\% 80 \% 81 /$ article/ viewFile/5768/4188

30. Polit DF, Beck CT, Owen SV. Is the CVI an acceptable indicator of content validity? Appraisal and recommendations. Res Nurs Health. 2007;30(4):459-67. doi: 10.1002/nur.20199

31. Zamanzadeh V, Ghahramanian A, Rassouli M, Abbaszadeh A, Alavi-Majd H, Nikanfar A-R. Design and Implementation Content Validity Study: dvelopment of an instrument for measuring patient-centered communication. J Caring Sci. 2015;4(2):165-78. doi: 10.15171/jcs.2015.017.

32. Martins GDA. Sobre confiabilidade e validade. RBGN. 2006;8(12):1-12

33. Curado MAS, Teles J, Marôco J. Análise de variáveis não diretamente observáveis: influência na tomada de decisão durante o processo de investigação. Rev Esc Enferm USP. 2014;48(1):146-52. http://dx.doi.org/10.1590/S0080623420140000100019 .

34. Rodrigues IB, Adachi JD, Beattie KA, MacDermid JC. Development and validation of a new tool to measure the facilitators, barriers and preferences to exercise in people with osteoporosis. BMC Musculoskelet Disord. 2017;18(1):540. doi: 10.1186/s12891-017-1914-5. 